\title{
Assessment of inpatient diabetes education throughout a structured questionnaire
}

\author{
Thaís Lins Dos Santos*, Flavia Fernanda Franco, Thalita Barreira Modena Cardim, Magda Tiemi Yamamoto, \\ Rodrigo Bomeny de Paulo, Gustavo Daher, Rogério Silicani Ribeiro, Jose Antonio Maluf de Carvalho, \\ Claudia Regina Laselva
}

From 20th Brazilian Diabetes Society Congress

Porto Alegre, Brazil. 11-18 November 2015

\section{Background}

Hospital admission is an opportunity for diabetes education. However, the efficiency of education may be compromised by stress, disease acuteness and the medication effects.

\section{Objective}

To test the efficiency of patient education using a question form based on a tool developed by American Association of Diabetes Educators.

\section{Materials and methods}

From January to May 2015, 92 patients were educated during hospitalization and were included in this pilot study. Since inclusion is ongoing, here we present partial Results. On average, age was $63+17$ yrs. and time of diagnosis was $13+2$ yrs. and 80 patients were on insulin. The average number of sessions were 2,8 (range 1-8). Previous A1c were available for 62 patients (average: 8,1\%) and were above $7 \%$ in 46 cases. Patients were evaluated using questionnaire concerning the perceived importance of diabetes care and the knowledge about DM, nutrition, physical activity, glycemic control and medications. For those on insulin, there were additional questions concerning insulin administration and storage, glucose monitoring, response to hypo and hyperglycemia and foot care. For each question, patients scored from 0 (no knowledge) to 10 (full knowledge). After intervention, 64 (66\%) were

\begin{tabular}{|l|l|l|}
\hline Question & Before & After \\
\hline Importance of DM care & $9.2 \pm 2.1$ & $9.3 \pm 1.9$ \\
\hline Glycemic control & $7.1 \pm 2.6$ & $7.7 \pm 2.8$ \\
\hline Knowledge about DM & $6.0 \pm 2.5$ & $7.1 \pm 2.6$ \\
\hline Nutrition & $6.5 \pm 3.1$ & $8.2 \pm 3.2$ \\
\hline Physical activity & $5.8 \pm 3.4$ & $8.1 \pm 2.8$ \\
\hline Medications for DM & $6.1 \pm 3.6$ & $7.7 \pm 2.8$ \\
\hline Insulin administration & $5.3 \pm 4.3$ & $7.1 \pm 3.6$ \\
\hline Insulin storage & $5.4 \pm 4.4$ & $7.3 \pm 3.7$ \\
\hline Glucose monitoring & $6.2 \pm 4.1$ & $8.2 \pm 3.2$ \\
\hline Response to hypoglycemia & $6.0 \pm 3.4$ & $8.1 \pm 2.8$ \\
\hline Response to hyperglycemia & $5.3 \pm 3.2$ & $7.3 \pm 3.1$ \\
\hline Influence of diet/exercise on DM & $5.8 \pm 3.4$ & $8.1 \pm 2.8$ \\
\hline
\end{tabular}

Figure 1 Scores for patients evaluated before and after education.

\footnotetext{
* Correspondence: thaislins@me.com

Hospital Israelita Albert Einstein, São Paulo, Brazil
}

(c) 2015 Dos Santos et al. This is an Open Access article distributed under the terms of the Creative Commons Attribution License (http://creativecommons.org/licenses/by/4.0), which permits unrestricted use, distribution, and reproduction in any medium, provided the original work is properly cited. The Creative Commons Public Domain Dedication waiver (http://creativecommons.org/ publicdomain/zero/1.0/) applies to the data made available in this article, unless otherwise stated. 
reevaluated with the same questionnaire. The major reasons for no reevaluation were discharge during weekend and discharge without notification.

\section{Results}

At baseline $(n=92)$, patients highly scored the importance diabetes care (average score: $9.2 \pm 2$ ) and glycemic control (7.8 \pm 3$)$ but recognized a lower level of knowledge about DM (6.2 \pm 3$)$, nutrition (6.8 \pm 3$)$, physical activity (6.3 \pm 3$)$ and medications $(6.4 \pm 4)$. For those 80 on insulin, there lower scores for knowledge about insulin administration $(6.2 \pm 4)$ and storage $(5.7 \pm 4)$, glucose monitoring $(6.6 \pm 4)$, response to hypoglycemia $(6.5 \pm 3)$ and hyperglycemia $(5.9 \pm 3)$. For patients evaluated before and after education, scores were described below (Figure 1).

\section{Conclusion}

By performing a structured evaluation, we documented an improvement in diabetes knowledge of hospitalized patients. Besides every patient has some knowledge of the disease, after the education guided by the question form, all patients increase their grades for each subject.

Published: 11 November 2015

doi:10.1186/1758-5996-7-S1-A173

Cite this article as: Dos Santos et al: Assessment of inpatient diabetes education throughout a structured questionnaire. Diabetology \& Metabolic Syndrome 2015 7(Suppl 1):A173.
Submit your next manuscript to BioMed Central and take full advantage of:

- Convenient online submission

- Thorough peer review

- No space constraints or color figure charges

- Immediate publication on acceptance

- Inclusion in PubMed, CAS, Scopus and Google Scholar

- Research which is freely available for redistribution

Submit your manuscript at www.biomedcentral.com/submit 